\title{
A Novel Postharvest Rot of Okra Pods Caused by Rhizoctonia solani in Brazil
}

\author{
Gilmar P. Henz, Carlos A. Lopes \& Ailton Reis \\ Embrapa Hortaliças, Cx. Postal 218, 70359-970 Brasília, DF, Brazil, e-mail: gilmar@cnph.embrapa.br
}

Author for correspondence: Gilmar P. Henz

HENZ, G.P., LOPES, C.A. \& REIS, A. A novel postharvest rot in okra pods caused by Rhizoctonia solani in Brazil. Fitopatologia Brasileira 32:237-240. 2007.

\begin{abstract}
Okra pods with unusual brown lesions and rot were collected in a local supermarket in Brasília DF. The objective of this paper was to characterize the causal agent, to fulfill Koch's postulates and to determine some conditions conducive to disease. The pathogen was identified as Rhizoctonia solani based on morphological characteristics which fitted the fungus description, such as pale to brown hyphae, with nearly right-angled side branches constricted at the base, hyphal cells 6-10 $\mu \mathrm{m}$ wide with a septum near the base. Five isolates were obtained from infected pods and identified as AG 1-IB anastomosis group. Wounded or unwounded okra pods cv. Santa Cruz 47 were inoculated with mycelium disks of $R$. solani and kept in humid chambers at $12{ }^{\circ} \mathrm{C}$ or $25^{\circ} \mathrm{C}$. After seven days at $25^{\circ} \mathrm{C}$, both wounded and unwounded pods were completely rotted and brown, while those kept at $12{ }^{\circ} \mathrm{C}$ showed small lesions ranging from 0.6 to $1.0 \mathrm{~mm}$ only in wounded pods. The pathogen was able to grow in different materials used for assembling crates and packs of horticultural products, such as pinewood, corrugated carton, plastic, Styrofoam and newspaper sheets when kept in humid chambers $\left(24{ }^{\circ} \mathrm{C}, 96 \% \mathrm{RH}\right)$. The disease occurrence can be related to careless handling practices and to the transmission of $R$. solani propagules by infected plant debris or soil particles. This is the first report of Rhizoctonia solani causing postharvest rot in okra pods in Brazil.
\end{abstract}

Additional keywords: Abelmoschus esculentus, immature fruit, disease.

\section{RESUMO}

Uma nova podridão pós-colheita de frutos de quiabo causada por Rhizoctonia solani

Frutos de quiabo apresentando podridão e lesões marrons foram coletados em um supermercado de Brasília DF. O objetivo deste trabalho foi identificar o agente causal e comprovar o envolvimento do fungo como causador da doença (Postulados de Koch) e determinar algumas condições favoráveis à ocorrência da doença em frutos de quiabo após a colheita. O patógeno foi identificado como Rhizoctonia solani baseado nas suas características morfológicas, como hifas marrons a ocre, com ramificações laterais em ângulos quase retos com constrições na base, células da hifa com 6-10 $\mu \mathrm{m}$ de largura com um septo perto da base. Cinco isolados foram obtidos dos frutos infectados e identificados como sendo do grupo de anastomose AG 1-IB. Frutos de quiabo cv. Santa Cruz 47 inoculados com discos de micélio de $R$. solani com e sem ferimentos e mantidos em câmaras úmidas, a $25^{\circ} \mathrm{C}$, por sete dias ficaram completamente apodrecidos pelo patógeno, com cor marrom, enquanto somente os frutos com ferimentos mantidos a $12{ }^{\circ} \mathrm{C}$ apresentaram lesões pequenas, variando de 0,6 a 1,0 mm de diâmetro. Em outro experimento, foi demonstrado que o patógeno foi capaz de crescer na superfície de diferentes materiais usados na confecção de embalagens de produtos hortícolas, como madeira de pinus, papelão corrugado, plástico, isopor e folhas de jornal mantidos em câmara úmida $\left(24{ }^{\circ} \mathrm{C}, 96 \%\right.$ UR). A ocorrência da doença está relacionada com manuseio pós-colheita inadequado, e a transmissão de propágulos do fungo junto com restos culturais ou partículas de solo. Este é o primeiro relato de $R$. solani causando podridão pós-colheita em frutos de quiabo no Brasil.

Palavras-chave adicionais: Abelmoschus esculentus, frutos imaturos, doenças.

Okra (Abelmoschus esculentus L.) is a popular vegetable crop in Southeastern and Northeastearn Brazil, where its immature pods are used in many regional dishes. Few okra cultivars are available on the Brazilian seed market, and the most important are 'Santa Cruz 47', 'Roxo', 'Amarelinho', 'Colhe Bem', 'Piranema', 'Campinas 1', and 'Campinas 2'. Cultivar 'Santa Cruz 47' is the one preferred by consumers and growers because of its cylindrical fruit shape, lower fiber content, early production and high yield. The usual form of okra commercialization in supermarkets and grocery stores is to display the fruits in open stands or in large plastic boxes, without refrigeration or wrapping.
Fresh, immature, green pods are the prime product, since older pods are fibrous, difficult to cook and hard to chew.

The most frequent postharvest problems of okra fruits are weight loss, color fading, darkening and rots caused mainly by fungi. This vegetable is classified as highly perishable because of its high respiration rate and high water content ( $\cong 90 \%)$, resulting in a quick loss of commercial value upon market display (Hardenburg et al., 1986; Snowdon, 1991; Della-Justina, 1998; Carvalho et al., 2002). Papers on conservation and storage of okra pods in Brazil have been published since the 80's (Martins et al., 1981; Della-Justina, 1998; Silva et al., 1999; Modolo et al., 
2000), but none of these papers considered the presence of plant pathogens as deteriorating agents.

Few pathogens have been reported as causal agents of diseases in okra fruits in Brazil and elsewhere, such as Choanephora cucurbitarum, Fusarium solani, Phytophthora palmivora and Rhizoctonia solani in Nigeria (Esuruoso et al., 1975); Rhizopus stolonifer in Romania, Phoma exigua in India, Geotrichum candidum in Egypt and $R$. solani in Malaysia (Snowdon, 1991). Bacterial blight caused by Pseudomonas syringae pv. syringae is essentially a field disease, but pods can also be affected (Snowdon, 1991), as reported in Brazil by Kimura et al. (1982). In Brazil, $R$. solani has been often associated with damping-off of several vegetable crops and is also a seedborne pathogen (Mendes et al., 1998), including okra seeds of cv. Santa Cruz 47 (Esteves et al., 1984; Fernandes et al., 1990). Seed transmission was not associated with fruit rot in any of these reports. Bolkan $\&$ Ribeiro (1985) obtained 131 isolates of $R$. solani from different hosts collected in Brazil, some of them causing rot in vegetable fruits such as eggplant and sweet pepper.

In 1996, okra fruits with brown lesions and rot were collected in a local supermarket in Brasília, Federal District, Brazil. Preliminary laboratory exam indicated the presence of a fungus with profuse mycelial growth and absence of conidia (Henz et al., 1996). Because okra pods are usually consumed within 2-3 days after harvest, the occurrence of this postharvest disease was unexpected. The objective of this paper was to identify the causal agent and to study some epidemiological components involved with the disease process not covered in an earlier preliminary report of this occurrence.

\section{Pathogen isolation and identification}

Rotted okra pods were examined in the Plant Pathology Laboratory at Embrapa Hortaliças, and mycelial growth was consistently associated with lesions. Small portions of lesion edges were taken with a sterile scalpel, superficially disinfested in a sodium hypochloride solution (1\%) and then plated in Petri dishes with PDA (potato dextrose agar) or WA (water agar). Five isolates were obtained from distinct infected pods. After three days of incubation at $25{ }^{\circ} \mathrm{C}$, fastgrowing mycelia grew on the surface of both media. Light microscopy and staining procedures of the fungal mycelia revealed thick brown hyphae, with nearly right-angled side branches, constricted at the base, hyphal cells $6-10 \mu \mathrm{m}$ wide with a septum near the base, and an average of 8 to 11 nuclei per cell, typical of Rhizoctonia solani (Sneh et al., 1991). Five isolates were characterized as anastomosis group AG1IB, according to standard procedures (Sneh et al., 1991) by Prof. Acelino C. Alfenas (Universidade Federal de Viçosa, Viçosa-MG, Brazil).

\section{Koch's Postulates}

Healthy green okra fruits of cv. Santa Cruz 47 were washed with tap water, superficially disinfested with sodium hypochloride $(1 \%)$, rinsed with sterile water and let dry at room temperature $\left(24{ }^{\circ} \mathrm{C} ; 78 \% \mathrm{RH}\right)$. Inoculation was performed either on fruits intact or wounded with entomological pins, followed by deposition of a plug of mycelial culture on the injured site. A plug of sterile PDA was used as a control. After inoculation, fruits were kept in plastic bags $(95 \% \mathrm{RH})$ for seven days in growth chambers with temperatures set at $25^{\circ} \mathrm{C}$ or $12{ }^{\circ} \mathrm{C}$. Disease evolution was assessed daily by visual examination of the pods.

Wounded pods maintained at $25^{\circ} \mathrm{C}$ showed symptoms two days after inoculation, and disease progressed rapidly. Seven days after inoculation, both wounded and intact pods maintained at $25^{\circ} \mathrm{C}$ were completely rotted, the pod's typical greenish color turning brown, and the infected tissues fully covered with mycelia (Figure 1A). Internally, immature seeds and placenta were infected up to $2 \mathrm{~cm}$ below the inoculation point, and the diseased tissues were light brown to black (Figure 1B), therefore explaining seed transmission of the pathogen. Externally, mycelia tend to be fluffy and lighter in color, forming a large number of dark sclerotia on the fruit surface. Pods kept at $12{ }^{\circ} \mathrm{C}$ developed smaller lesions, ranging from 0.6 to $1.0 \mathrm{~mm}$ of diameter.

Although pod rot has not been frequently observed as a postharvest disease of okra in Brazil, it has been reported in tropical countries such as Nigeria (Esuruoso
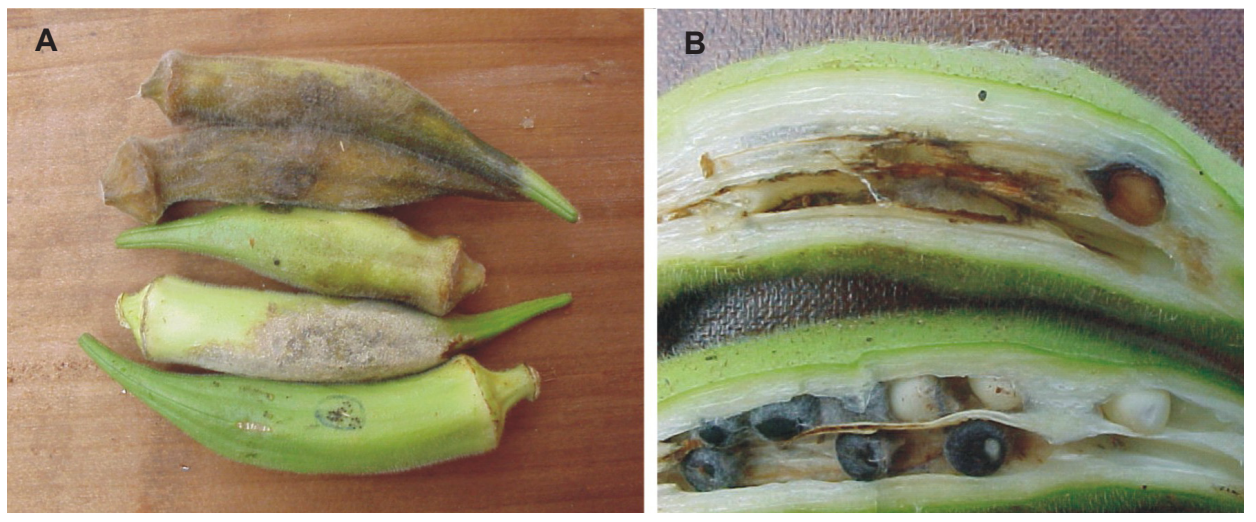

FIG. 1 - Okra fruit rot caused by Rhizoctonia solani at seven days after inoculation $\left(25{ }^{\circ} \mathrm{C} ; 96 \%\right.$ $\mathrm{RH})$ : A. pods showing distinct degrees of rotting; injured not-inoculated fruit at bottom (control treatment); B. details of rotting of placenta tissues and immature seeds. 
et al., 1975), causing wet rot of leaves, flowers, and fruits and damping-off in seedlings, as well as in Malaysia (Tai \& Musa, 1975, quoted by Snowdon, 1991), infecting young fruits inoculated with or without wounding. In Brazil, the disease probably developed during commercialization because of poor handling practices, which frequently result in fruit injuries, and the exposure of fruits in wooden or plastic crates mixed with infected leaf remains and flowers. Furthermore, fruits positioned at the bottom of supermarket stands are submitted to a conducive microclimate, favoring disease, with temperatures ranging from $23{ }^{\circ} \mathrm{C}$ to $26^{\circ} \mathrm{C}$ and relative humidity from $75 \%$ to $95 \%$.

If the disease occurs under field conditions, okra seeds can easily get infected and transmit the disease. Rhizoctonia solani has been detected in okra seeds infecting $1-4 \%$ of $\mathrm{cv}$. Santa Cruz 47, widely cultivated in Brazil. Seed infection resulted in necrotic lesions on roots and hypocotyls of okra seedlings (Esteves et al., 1984). A careful selection of pods for seed production is an important measure to prevent the disease, especially when harvest coincides with humid or rainy periods, favorable to infection.

Since $R$. solani is a typical soilborne fungus and fruits of okra cv. Santa Cruz 47 are usually produced about $60 \mathrm{~cm}$ above the soil line, the pathogen was probably carried with infected plant debris (leaves, peduncles) or soil particles present in the old wooden boxes used to collect the pods in the field. By simulating this condition, the pathogen easily infected flower remains and leaves collected in an okra field and inoculated with plugs of $R$. solani mycelia after three days at $25{ }^{\circ} \mathrm{C}(95 \% \mathrm{RH})$. Plant debris are usually found mixed with pods at the supermarkets and groceries and can be a potential source of inocula. Pinewood crates used to collect and transport okra are reusable and in many instances carry soil particles, another potential source of inocula. The internal parts of the pinewood crates (known as "K" boxes) are usually covered by used sheets of newspaper to avoid direct contact of the fruits with the rough wood surface, which can cause abrasion, and therefore sites for pathogen entry, and also blackening of the fruits. Apparently, this was the first report of $R$. solani causing a postharvest rot in okra pods in Brazil.

\section{Growth of Rhizoctonia solani in materials used for crate crafting}

The mycelium growth of $R$. solani was tested in materials used for crafting boxes and crates for packing okra and other horticultural products in Brazil, such as pinewood, plastic boxes, corrugated paper, Styrofoam and used newspaper sheets. The fungus was cultivated on PDA for four days, after which plugs of $0.5 \mathrm{~cm}$ diameter were placed in the center of the segments measuring $25 \mathrm{~cm}^{2}(5 \times 5 \mathrm{~cm})$ of the different materials, with three replicates for each material. All inoculated segments were kept at $12{ }^{\circ} \mathrm{C}$ and $24{ }^{\circ} \mathrm{C}$ combined with two relative humidities (65\% and $96 \%)$ for seven days. The mycelial radial growth was recorded daily for seven days.
The fungus grew on the surface of all materials used for boxes or crate manufacturing (pinewood, corrugated carton, plastic, Styrofoam and used newspaper sheets) kept at temperature of $24{ }^{\circ} \mathrm{C}$ and $96 \%$ RH. Sclerotia were observed only in plastic and Styrofoam. Fungal growth was halted in all substrates in a less conducive condition, at lower temperature $\left(12{ }^{\circ} \mathrm{C}\right)$ and relative humidity $(65 \%)$. The ability of $R$. solani to grow in all the substrates at 24 ${ }^{\circ} \mathrm{C}$ and $96 \% \mathrm{RH}$ partly explains disease outbreaks under supermarket conditions.

Based on these results, the postharvest rot of okra pods caused by $R$. solani is related to the high susceptibility of the fleshy, immature fruits combined with the conducive prevailing conditions of perishable products in the open nonrefrigerated outlet displays of the retail markets. At $12{ }^{\circ} \mathrm{C}$, wrapped, intact pods can be maintained up to seven days and halt the development of the disease, as well as reduce the growth of the pathogen in some materials used for packing.

\section{AKNOWLEDGEMENTS}

The authors are thankful to Dr. Acelino Couto Alfenas, from the Department of Plant Pathology, Universidade Federal de Viçosa, for providing the identification of $R$. solani anastomosis group.

\section{REFERENCES}

BOLKAN, H.A. \& RIBEIRO, W.R.C. Anastomosis groups and pathogenicity of Rhizoctonia solani isolates from Brazil. Plant Disease 69:599-601. 1985.

CARVALHO, M.J., MOTA, W.F., FIRME, L.P., GALVÃO, H.L. \& FINGER, F.L. Conservação pós-colheita de frutos de quiabeiro em função da temperatura de armazenamento. Horticultura Brasileira 20. Suplemento CD-Rom. 2002.

DELLA-JUSTINA, M.E. Conservação pós-colheita do quiabo influenciada por idade, dano mecânico, filme de PVC e temperatura. Dissertação de Mestrado. Viçosa MG. Universidade Federal de Viçosa. 1998.

ESTEVES, M.C.F., ALMEIDA, O.C., COELHO, R.C., LIBERAL, O.H.T. \& ROBBS, C.F. Detecção e identificação de fungos associados a sementes de duas cultivares de quiabeiro (Abelmoschus esculentus L.) de diferentes origens. Niterói RJ. PESAGRO-RIO, 1984. (Pesquisa em Andamento, 30)

ESURUOSO, O.F., OGUNDIRAN, S.A., CHHEDA, H.R. \& FATOKUN, D.O. Seedborne fungi and some fungal diseases of okra in Nigeria. Plant Disease Repórter 58:660-663. 1975.

FERNANDES, M.C.A., ALMEIDA, O.A., CUNHA, R. \& ROBBS, C.F. Estudos preliminares sobre a sanidade de sementes de quiabeiro procedentes de alguns municípios do estado do Rio de Janeiro. Revista Brasileira de Sementes 12:37-43. 1990.

HARDENBURG, R.E., WATADA, A.E. \& WANG, C.Y. The 
Commercial Storage of Fruits, Vegetables, and Florist and Nursery Stocks. Washington DC. USDA, 1986. (Agriculture Handbook, 66).

HENZ, G.P., NOJOSA, G.B.A. \& MENDONÇA, N.D. Ocorrência de Rhizoctonia solani como patógeno pós-colheita de frutos de quiabo. Horticultura Brasileira 14:89. 1996.

KIMURA, O., RIBEIRO, R.L.D. \& ROBBS, C.F. Apodrecimento de frutos e crestamento foliar do quiabeiro causados por Pseudomonas syringae. Arquivos da Universidade Federal Rural do Rio de Janeiro, v.5. 1982. pp. 105-110.

MARTINS, R.M.M.S., LEAL, N.R. \& COELHO, R.G. Avaliação da capacidade de conservação natural pós-colheita de frutos do quiabeiro. Niterói RJ. PESAGRO-RIO. 1981. (Comunicado Técnico, 76)

MENDES, M.A.S., SILVA, V.L., DIANESE, J.C., FERREIRA, M.A.S.V., SANTOS, C.E.N., NETO, E.G., URBEN, A.F. \& CASTRO, C. Fungos em Plantas no Brasil. Brasília DF. Embrapa SPI/Embrapa Cenargen. 1998.

MODOLO, V.A., KLUGE, R.A. \& JACOMINO, A.P. Pós-colheita de quiabos submetidos a refrigeração e embalagem plástica. Horticultura Brasileira 18:298-299. 2000.

MOHAMMED, M. \& BRECHT, J.K. Immature fruit vegetables. In: Bartz, J.A. \& Brecht, J.K. (Eds.) Postharvest Physiology and Pathology of Vegetables. New York NY. Marcel Dekker. 2003. pp. 671-690.

SILVA, A.M., JUSTINA-DELLA, M.E. \& FINGER, F.L. Avaliação do efeito de três temperaturas de armazenamento e de filme PVC sobre a conservação do fruto do quiabeiro. Horticultura Brasileira 17:325. 1999. (Resumo)

SNEH, B.; BURPEE, L.; OGOSHI, A. Identification of Rhizoctonia species. St. Paul: APS Press, 1991. 135p.

SNEH, G., JABAHI-HARE, S., NEATE, S. \& DIJST, G. Rhizoctonia species: taxonomy, molecular biology, ecology, pathology, and disease control. Dordrecht. Kluwer Academic Publishers. 1996.

SNOWDON, A.L. A Colour Atlas of Post-Harvest Diseases and Disorders of Fruits and Vegetables - vol. 2: Vegetables. London. Wolfe Scientific Ltd. 1991.

Received 17 June 2004 - Accepted 5 March 2007 - FB 4076 